\title{
WYZNACZNIKI DECYZJI ZAKUPOWYCH TOWARÓW KONSUMPCYJNYCH MIESZKAŃCÓW POZNANIA I WIELKOPOLSKI
}

\section{WPROWADZENIE}

Podstawowym celem opracowania jest identyfikacja i określenie ważności determinant zakupu towarów konsumpcyjnych ${ }^{1}$ (artykułów spożywczych, chemii gospodarczej i kosmetyków, odzieży i obuwia oraz dóbr trwałego użytku) w Poznaniu oraz w pozostałej części Wielkopolski (pozostali mieszkańcy bez miasta Poznania). Podstawą do realizacji przedstawionego celu są zbiory źródłowe, które stanowią informacje wtórne w formie wyników badań zrealizowanych w kraju w latach 2010-2013 przez różne instytucje badawcze oraz wyniki systematycznie od 2008 r. prowadzonych badań konsumenckich w Poznaniu i Wielkopolsce na Wydziale Towaroznawstwa Uniwersytetu Ekonomicznego w Poznaniu ${ }^{2}$. Na bazie tych ostatnich wyodrębniono zbiory czynników dla każdej kategorii produktów na podstawie pomiaru przeprowadzonego za pomoca pięciostopniowej skali Likerta ${ }^{3}$. Analizy częściowe wyników badań były przedstawiane wcześniej w różnych publikacjach krajowych, ale artykuł jest pierwszym opracowaniem prezentujacym w pełnym zakresie wyznaczniki zakupów mieszkańców stolicy Wielkopolski oraz reszty mieszkańców województwa4

Badania zachowań rynkowych zarówno konsumentów indywidualnych, jak i gospodarstw domowych to podstawowe i standardowe zadania pod-

1 Towary służące do zaspokajania potrzeb konsumentów w zakresie wyżywienia oraz innych potrzeb bytowych w szeroko rozumianym zakresie, http://old.stat.gov.pl/gus/definicje_PLK_ HTML.htm?id=POJ-952.htm (dostęp: 15.06.2014).

2 Zakresy badań empirycznych: 1) podmiotowy - konsumenci wybranych kategorii produktów, 2) przedmiotowy - uwarunkowania kształtujące wybory konsumencie, 3) przestrzenny - województwo wielkopolskie, 4) czasowy - lata 2011-2013. Wielkość próby badawczej w 2011 r. wyniosła 1513 badanych, natomiast w 2013 r. - 1271. Dobór próby miał charakter kwotowy (uwzględnione cechy: płeć, wiek, miejsce zamieszkania). Analiza zebranych danych przeprowadzona została za pomoca programu IBM SPSS Statistics ver. 21.

${ }^{3}$ Wartości na skali Likerta zdefiniowane zostały w następujący sposób: '1' oznaczała 'brak znaczenia', '2' definiowała czynnik jako 'nieistotny (mało ważny)', '3' jako 'średnio ważny (ani istotny, ani nieistotny)', '4' definiowała czynnik jako 'istotny (ważny)', natomiast '5’ określała czynnik jako 'decydujący (najważniejszy)'.

${ }^{4}$ Zob. P. Bartkowiak, B. Sojkin, Determinanty zakupu towarów przez polskich konsumentów, „Marketing i Rynek” 2014, nr 8 (sierpień); B. Sojkin (red.), Zachowania zakupowe i konsumpcyjne mieszkańców i Wielkopolski, IBRKiK, Warszawa 2013, s. 75-105. 
miotów występujących po stronie podażowej, których głównym celem rynkowym jest zaspokajanie zgłaszanych przez konsumentów potrzeb indywidualnych i zbiorowych. Badania koncentruja się przede wszystkim na zachowaniach nabywczych i konsumpcyjnych i obejmuja szerokie spektrum problemów, których wyjaśnienie jest niezbędne, aby osiagnąć cele polityki rynkowej każdego podmiotu, a szczególnie przygotowanie strategii sprzedaży wyrobów i usług 5 . W artykule skoncentrowano się tylko na konsumentach indywidualnych i czynnikach kształtujacych ich zachowania nabywcze. Głównym aspektem podejmowanych analiz uzyskanych wyników jest identyfikacja czynników, które wpływają bezpośrednio i pośrednio na decyzję konsumenta o zakupie wybranych towarów i mogą stanowić pomoc w procesie budowania modelu mentalnego konsumenta w części dotyczacej zakupowego procesu decyzyjnego ${ }^{6}$. W literaturze przedmiotu bądź wielu aktualnych opracowaniach podsumowujacych badania rynkowych zachowań konsumenckich, a także wypowiedziach ekspertów i przedstawicieli przedsiębiorstw handlowych można spotkać się z bardzo jednoznacznymi wskazaniami, że o zakupie w przypadku większości produktów decydują: cena, jakość i marka ${ }^{7}$. Jednak nie zawsze prowadzone pogłębione badania konsumenckie potwierdzają tak jednoznaczne sformułowania o głównej roli wymienionych determinant ${ }^{8}$. Niewątpliwie wymienione wyżej zmienne należą do zbioru tych, które wpływają na decyzje nabywcze (zakupowe) konsumenta indywidualnego, ale ich znaczenie bardzo wyraźnie się różnicuje, gdy weźmie się pod uwagę różne kategorie produktów, wielkość zbioru poddanych ocenie czynników (liczba), przynależność konsumenta do grupy społeczno-zawodowej, poziom zamożności, miejsca zamieszkania czy charakter badania (cel, technikę badawczą czy technikę pomiaru). Lista determinant uznanych za zbiór zmiennych, poddany ocenie przez konsumentów województwa wielkopolskiego, została ustalona na podstawie przeprowadzonego badania wstępnego mieszkańców miasta Poznania i województwa, którzy wskazywali czynniki uwzględniane przez nich przy podejmowaniu decyzji o zakupie różnych grup produktów. Ponadto ustalenia te weryfikowano czynnikami/determinantami pojawiajaccymi się badaniach konsumenckich realizowanych przez inne ośrodki badawcze, a także nowymi zgłaszanymi przez uczestników realizowanych badań.

${ }_{5}$ Zob. Polak na zakupach - najważniejsza jakość produktu - badania przeprowadzone na zlecenie firmy Henkel przez GFK Austria we wrześniu 2010 r.; Mania kupowania, czyli o postawach konsumenckich Polaków - CBOS, Warszawa, styczeń 2011; Gdzie i jak kupujemy żywność, CBOS, Warszawa, lipiec 2013; Syndicated Price Image Study 2013, ARC Rynek i Opinia i Vocatus, marzec/ kwiecień 2013.

${ }^{6}$ E. Kieżel (red.), Rynkowe zachowania konsumentów, Wyd. AE w Katowicach, Katowice 2000, s. 103-107; Z. Kędzior, E. Kieżel (red.), Konsumpcja i rynek w warunkach zmian systemowych, PWE, Warszawa 2002, s. 36; P. Legrenzi, V. Girotto, Mental Models in Reasoning and Decision Making Processes, w: J. Oakhill, A. Garnham (red.), Mental Models in Cognitive Science, Taylor and Francis, Psychology Press, Hove, Sussex (Erlbaum UK), 1996, s. 95-118.

7 Jak kupuje nowe pokolenie, Shopping Show 2013, Warszawa, maj 2013, s. 8; Zwyczaje zakupowe Polaków, Shopping Show, Warszawa, maj 2013.

8 B. Sojkin et al., Konsument wobec innowacji produktowej, Wyd. UEP, Poznań 2009, s. 37-50, 118-130; A. Kusińska (red.), Konsumpcja a rozwój gospodarczy regionów, PWE, Warszawa 2011, s. $189-193$. 


\section{DETERMINANTY ZAKUPÓW ŻYWNOŚCI}

Postępowanie zmierzające do ustalenia ważności poszczególnych czynników zakupowych w ramach każdej kategorii produktów i opisujacego ja zbioru zmiennych było identyczne, albowiem obliczano ich wartości średnie. Dalej uwzględniano dwie cechy różnicujące badaną zbiorowość, a mianowicie miejsce zamieszkania oraz płeć jako przyczyny istotnych statystycznie różnic. Uzyskane wartości dla wyróżnionych 29 determinant zakupu artykułów spożywczych przedstawiono na wykresie 1. Wyniki te pokazuja, że w $2013 \mathrm{r}$. do zbioru najważniejszych determinant zakupowych artykułów spożywczych zaliczyć należy przede wszystkim: cenę $(\bar{x}=4,25$ - Poznań; $\bar{x}=4,38$ - Wielkopolska), smak produktu ( $\bar{x}=4,22$ - Poznań; $\bar{x}=4,20$ - Wielkopolska), termin ważności produktu ( $\bar{x}=4,40$ - Poznań; $\bar{x}=4,37$ - Wielkopolska) oraz jakość produktu ( $\bar{x}=4,12$ - Poznań; $\bar{x}=4,12$ - Wielkopolska). Tak więc mieszkańcy obu rozpatrywanych rejonów nie wykazują różnic w ocenie ważności trzech czynników. Z kolei do tych czynników, które należą do najmniej istotnych w procesie podejmowania decyzji o zakupie artykułów spożywczych, należą: nowość produktu ( $\bar{x}=2,52$ - Poznań; $\bar{x}=2,65$ - Wielkopolska) oraz kraj pochodzenia produktu ( $\bar{x}=2,62-$ Poznań; $\bar{x}=2,74-$ Wielkopolska). I w tym przypadku pojawia się zadziwiająca zgodność ocen, aczkolwiek dziwić może brak znaczenia nowości produktu i kraju pochodzenia, co może być związane $\mathrm{z}$ „efektem oswojenia” konsumentów. Czyli bardzo znaczna liczba pojawiajacych się nowości na rynku żywnościowym i postępująca globalizacja rynków doprowadziły do oswojenia się nabywców oraz traktowania tej sytuacji jako stałego elementu półki sklepowej i realizowanych zakupów. W przypadku pozostałych zmiennych należących do badanego zbioru determinant uzyskane wartości średnie oscylowały wokół oceny określanej jako średnio ważny (ani istotny, ani nieistotny).

Wskazać można na zbiory determinant, których oceny odzwierciedlone przez średnią arytmetyczną są uzależnione od miejsca zamieszkania badanych osób. Mianowicie w przypadku konsumentów mieszkających w Poznaniu do czynników o większym znaczeniu zaliczyć można determinanty związane ze smakiem i składem nabywanych produktów, zdrowotnościa, ekologicznościa i wartością energetyczna produktów. Dodatkowo ważniejsze dla nich okazały się preferencje i konieczność zakupu, odczucie zaspokojenia potrzeby, zalecenia lekarza oraz wielkość opakowania produktów spożywczych. Z kolei dla osób mieszkających poza stolicą województwa większe znaczenie niż dla mieszkańców Poznania posiadały: wielkość gospodarstwa domowego, obsługa klienta czy miejsce zakupu, aczkolwiek różnice w średnich ocen nie są znaczące.

Kolejnym etapem postępowania badawczego było porównanie wartości średnich (znaczenia) czynników zakupowych artykułów spożywczych w latach 2011-2013, do którego wykorzystano test $t$ dla grup niezależnych ${ }^{9}$. Test $t$

9 Test $t$ jest powszechnie stosowaną metodą oceny różnic między średnimi w dwóch zbiorach. Podawany w wynikach testu $t$ poziom $p$ reprezentuje prawdopodobieństwo błędu związanego z przyjęciem hipotezy o istnieniu różnic między średnimi - G. Wieczorkowska, J. Wierzbiński, Statystyka od teorii do praktyki, Scholar, Warszawa 2011, s. 214-215. 


\section{Wykres 1}

Ważność determinant zakupu artykułów spożywczych w Poznaniu i w Wielkopolsce w latach 2011-2013

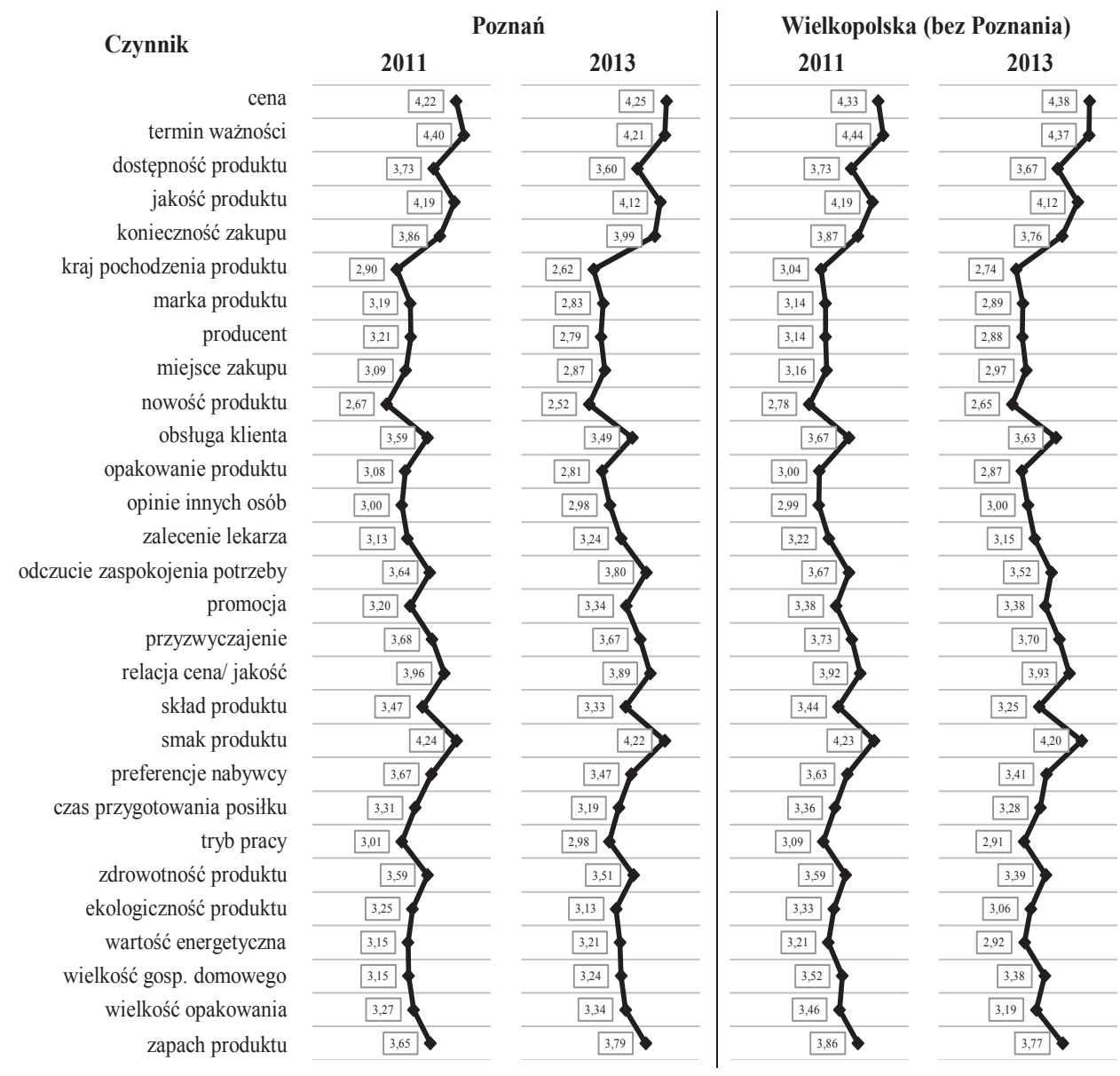

Źródło: opracowanie własne.

zastosowano do porównania grup kobiet i mężczyzn mieszkających w Poznaniu albo w Wielkopolsce. Porównanie znaczenia determinant zakupowych artykułów spożywczych w badanych okresach w przypadku kobiet mieszkających w Poznaniu wskazuje na występowanie statystycznie istotnych różnic w przypadku dziesięciu czynników, a średni poziom znaczenia determinant zakupowych był prawie w każdym przypadku wyższy w 2011 r. wyjątek stanowiły promocje, których znaczenie wzrosło w 2013 r. (tab. 1). $\mathrm{Na}$ tej podstawie można sformułować wniosek, że w przypadku kobiet mieszkajacych w Poznaniu determinanty wymienione w tabeli 1 traktowane sa jako „standardy zakupowe” i ich znaczenie w wyborach konsumpcyjnych maleje. 


\section{Tabela 1}

Porównanie znaczenia determinant zakupu artykułów spożywczych w grupie kobiet w Poznaniu w latach 2011-2013

\begin{tabular}{|c|c|c|c|}
\hline Czynnik & 2011 & 2013 & $t / p$ \\
\hline termin ważności & 4,44 & 4,27 & $2,130^{*}$ \\
\hline kraj pochodzenia produktu & 2,93 & 2,51 & $3,233^{* * *}$ \\
\hline marka produktu & 3,21 & 2,64 & $4,648^{* * *}$ \\
\hline producent & 3,24 & 2,62 & $5,099 * * *$ \\
\hline miejsce zakupu & 3,14 & 2,76 & $3,013 * *$ \\
\hline nowość produktu & 2,74 & 2,37 & $2,784^{* *}$ \\
\hline obsługa klienta & 3,72 & 3,43 & $2,682^{* *}$ \\
\hline opakowanie produktu & 3,12 & 2,78 & $2,870^{* *}$ \\
\hline promocja & 3,15 & 3,54 & $-3,132^{* *}$ \\
\hline skład produktu & 3,56 & 3,32 & $2,120^{*}$ \\
\hline
\end{tabular}

Źródło: opracowanie własne.

Z kolei w przypadku mężczyzn mieszkajacych w Poznaniu zbiór jest zdecydowanie mniej liczny (tab. 2), albowiem porównanie znaczenia determinant zakupu pozwoliło na identyfikację trzech zmiennych różniących się statystycznie między rokiem 2011 a 2013.

\section{Tabela 2}

Porównanie znaczenia determinant zakupu artykułów spożywczych w grupie mężczyzn w Poznaniu w latach 2011-2013

\begin{tabular}{|l|c|c|c|}
\hline \multicolumn{1}{|c|}{ Czynnik } & $\mathbf{2 0 1 1}$ & $\mathbf{2 0 1 3}$ & $\boldsymbol{t} / \boldsymbol{p}$ \\
\hline termin ważności & 4,37 & 4,10 & $2,863^{* * *}$ \\
\hline dostępność produktu & 3,77 & 3,55 & $2,123^{*}$ \\
\hline preferencje nabywcy & 3,73 & 3,51 & $1,980^{*}$ \\
\hline \multicolumn{2}{|l}{$t$ - statystyka $t ; p-$ poziom istotności; ${ }^{*} p \leq 0,05 ; * * p \leq 0,01 ; * * * p \leq 0,001$} \\
\hline
\end{tabular}

Źródło: opracowanie własne. 
Analiza wyników w tabeli 3 oraz porównanie ich ze statystycznie istotnymi różnicami występującymi w badanym okresie w grupie kobiet mieszkajacych w Poznaniu pozwalają na wyodrębnienie zbioru czynników wspólnych, w zakresie których występują statystycznie istotne różnice (kraj pochodzenia produktu, marka produktu, producent, miejsce zakupu i skład produktu) oraz zbiorów czynników różnicujących znaczenie determinant zakupu artykułów spożywczych ze względu na miejsce zamieszkania. Zatem w przypadku konsumentek mieszkających w Poznaniu zmianie uległo znaczenie terminu ważności, nowości i opakowania produktu, obsługi klienta oraz promocji sprzedaży. Natomiast kobiety mieszkajace poza Poznaniem mniejszą wagę przywiązywały do zdrowotności, ekologiczności i wartości energetycznej produktu, konieczności zakupu, preferencji nabywcy i trybu pracy oraz wielkości opakowania.

\section{Tabela 3}

Porównanie znaczenia determinant zakupu artykułów spożywczych w grupie kobiet w Wielkopolsce (bez Poznania) w latach 2011-2013

\begin{tabular}{|l|c|c|c|}
\hline \multicolumn{1}{|c|}{ Czynnik } & $\mathbf{2 0 1 1}$ & $\mathbf{2 0 1 3}$ & $\boldsymbol{t} / \boldsymbol{p}$ \\
\hline konieczność zakupu & 3,95 & 3,79 & $2,751^{* *}$ \\
\hline kraj pochodzenia produktu & 3,10 & 2,83 & $3,774^{* * *}$ \\
\hline marka produktu & 3,12 & 2,95 & $2,411^{*}$ \\
\hline producent & 3,12 & 2,90 & $3,248^{* * *}$ \\
\hline miejsce zakupu & 3,20 & 3,00 & $2,925^{* *}$ \\
\hline odczucie zaspokojenia potrzeby & 3,68 & 3,55 & $2,068^{*}$ \\
\hline skład produktu & 3,60 & 3,43 & $2,633^{* *}$ \\
\hline preferencje nabywcy & 3,66 & 3,43 & $3,726^{* * *}$ \\
\hline tryb pracy & 3,13 & 2,97 & $2,219^{*}$ \\
\hline zdrowotność produktu & 3,78 & 3,58 & $3,350^{* * *}$ \\
\hline ekologiczność produktu & 3,46 & 3,25 & $3,196^{* * *}$ \\
\hline wartość energetyczna & 3,38 & 3,13 & $3,537^{* * *}$ \\
\hline wielkość opakowania & 3,55 & 3,33 & $3,426^{* * *}$ \\
\hline$t-$ statystyka $t ; p-$ poziom istotności; $* p \leq 0,05 ; * * p \leq 0,01 ; * * * p \leq 0,001$ & \\
\hline
\end{tabular}

Źródło: opracowanie własne na podstawie przeprowadzonych badań empirycznych.

Natomiast w grupie mężczyzn mieszkających poza Poznaniem wyniki testu $t$ ujawniły zdecydowanie więcej statystycznie istotnych różnic (15), niż to miało miejsce w przypadku mężczyzn mieszkających w Poznaniu. Uzyskane wyniki każdorazowo wskazują na malejącą tendencję znaczenia wszystkich wyróżnionych czynników (tab. 4). 


\section{Tabela 4}

Porównanie znaczenia determinant zakupu artykułów spożywczych w grupie mężczyzn w Wielkopolsce (bez Poznania) w latach 2011-2013

\begin{tabular}{|c|c|c|c|}
\hline Czynnik & 2011 & 2013 & $t / p$ \\
\hline jakość produktu & 4,11 & 3,99 & $2,437^{*}$ \\
\hline kraj pochodzenia produktu & 2,96 & 2,65 & $4,326^{* * *}$ \\
\hline marka produktu & 3,14 & 2,85 & $4,248^{* * *}$ \\
\hline producent & 3,14 & 2,87 & $3,929 * * *$ \\
\hline miejsce zakupu & 3,12 & 2,96 & $2,388^{*}$ \\
\hline opakowanie produktu & 2,96 & 2,77 & $2,910 * *$ \\
\hline odczucie zaspokojenia potrzeby & 3,66 & 3,49 & $2,492^{*}$ \\
\hline skład produktu & 3,23 & 3,07 & $2,208^{*}$ \\
\hline preferencje nabywcy & 3,59 & 3,40 & $3,040^{* *}$ \\
\hline tryb pracy & 3,03 & 2,84 & $2,580^{* *}$ \\
\hline zdrowotność produktu & 3,37 & 3,21 & $2,251^{*}$ \\
\hline ekologiczność produktu & 3,18 & 2,87 & $4,446 * * *$ \\
\hline wartość energetyczna & 3,01 & 2,71 & $4,096^{* * *}$ \\
\hline wielkość gosp. domowego & 3,40 & 3,23 & $2,390^{*}$ \\
\hline wielkość opakowania & 3,35 & 3,06 & $4,382^{* * *}$ \\
\hline
\end{tabular}

Źródło: opracowanie własne.

\section{DETERMINANTY ZAKUPÓW ARTYKUŁÓW CHEMICZNYCH I KOSMETYKÓW}

Artykuły chemiczne i kosmetyki stanowiły drugą kategorię towarów, dla których został wyodrębniony zbiór 24 zmiennych, odzwierciedlajacy determinanty zakupów wskazywane przez konsumentów i zweryfikowane przez ekspertów. Procedura jego wyznaczenia była identyczna jak w przypadku artykułów żywnościowych, podobnie jak i przebieg przeprowadzonej oceny w ramach zrealizowanego badania. Obliczone średnie wartości ważności poszczególnych czynników dla tej kategorii produktów zostały zaprezentowane na wykresie 2 . 


\section{Wykres 2}

Ważność determinant zakupu chemii gospodarczej i kosmetyków w Poznaniu i w Wielkopolsce w latach 2011-2013

Czynnik

$$
\begin{array}{r}
\text { cena } \\
\text { dostępność produktu } \\
\text { jakość produktu } \\
\text { konieczność zakupu } \\
\text { konsystencja produktu } \\
\text { kraj pochodzenia produktu } \\
\text { łatwość użycia produktu } \\
\text { marka produktu } \\
\text { producent } \\
\text { miejsce zakupu produktu } \\
\text { nowość produktu } \\
\text { obsługa klienta } \\
\text { opakowanie produktu } \\
\text { opinie innych osób } \\
\text { promocja } \\
\text { przeznaczenie produktu } \\
\text { przyzwyczajenie } \\
\text { relacja cena/ jakość produktu } \\
\text { skład produktu } \\
\text { skuteczność produktu } \\
\text { szkodliwość produktu } \\
\text { wielkość opakowania } \\
\text { wydajność produktu } \\
\text { zapach produktu }
\end{array}
$$$$
\text { Czynnik }
$$

Poznań 2011

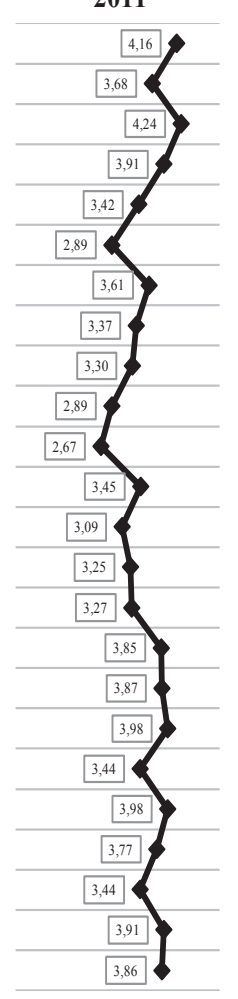

2013

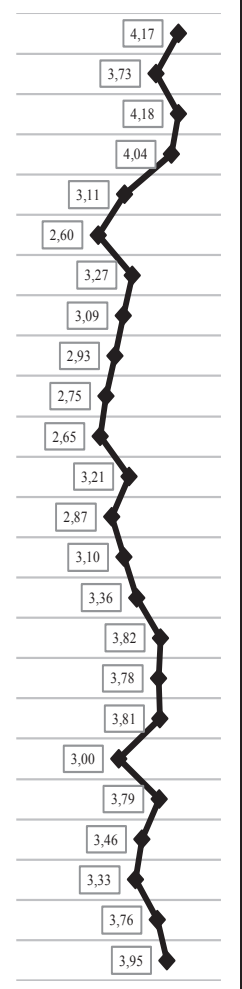

Wielkopolska (bez Poznania)

2011

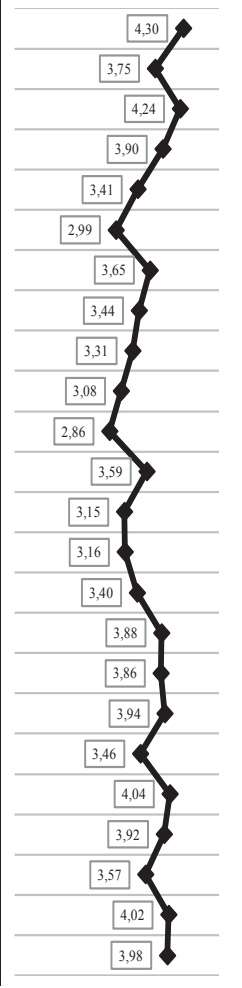

2013

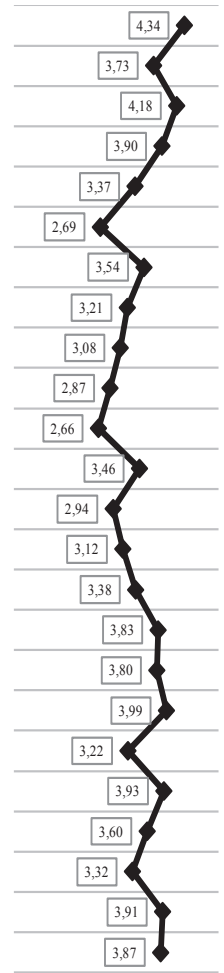

Źródło: opracowanie własne.

Wyniki prezentowane na wykresie 2 wskazują na dominujące znaczenie w 2013 r. ceny ( $\bar{x}=4,17$ - Poznań; $\bar{x}=4,34$ - Wielkopolska) oraz jakości nabywanych produktów ( $\bar{x}=4,18$ - Poznań; $\bar{x}=4,18$ - Wielkopolska). W dalszej kolejności wskazane zostały: konieczność zakupu $(\bar{x}=4,04-$ Poznań; $\bar{x}=3,90$ - Wielkopolska), zapach produktu ( $\bar{x}=3,95$ - Poznań; $\bar{x}=3,87$ - Wielkopolska) oraz jego przeznaczenie $(\bar{x}=3,82-$ Poznań; $\bar{x}=3,83$ - Wlkp.). Natomiast wśród czynników bez znaczenia dla konsumenta w procesie nabywczym kosmetyków i chemii gospodarczej wskazać należy przede wszystkim nowość produktu $(\bar{x}=2,65$ - Poznań; $\bar{x}=2,66$ - Wielkopolska) oraz kraj jego pochodzenia $(\bar{x}=2,60$ - Poznań; $\bar{x}=2,69$ - Wielkopolska). Porównanie znaczenia wyodrębnionych czynników zakupowych dla mieszkańców Poznania i Wielkopolski pozwala dostrzec, że są one równoważne lub ważniejsze dla Wielkopolan. Mieszkańcy Poznania większe znaczenie przywiązują jedynie do konieczności zakupu oraz zapachu produktu. 
Podobnie jak w przypadku żywności do porównania znaczenia determinant zakupowych artykułów chemii gospodarczej i kosmetyków w latach 2011-2013 wykorzystano test $t$. Pozwolił on na wskazanie statystycznie istotnych różnic między grupami badanych osób - w grupie kobiet mieszkających w Poznaniu zidentyfikowano różnice w zakresie dziewięciu czynników. Znaczenie tych czynników okazało się każdorazowo wyższe w 2011 r. (tab. 5).

\section{Tabela 5}

Porównanie znaczenia determinant zakupu chemii gospodarczej i kosmetyków w grupie kobiet w Poznaniu w latach 2011-2013

\begin{tabular}{|l|c|c|c|}
\hline \multicolumn{1}{|c|}{ Czynnik } & $\mathbf{2 0 1 1}$ & $\mathbf{2 0 1 3}$ & $\boldsymbol{t} / \boldsymbol{p}$ \\
\hline konsystencja produktu & 3,61 & 3,19 & $3,852^{* * *}$ \\
\hline kraj pochodzenia produktu & 3,06 & 2,55 & $4,723^{* * *}$ \\
\hline łatwość użycia produktu & 3,73 & 3,31 & $2,864^{* * *}$ \\
\hline marka produktu & 3,47 & 3,10 & $3,212^{* * *}$ \\
\hline producent & 3,40 & 3,00 & $3,622^{* * *}$ \\
\hline obsługa klienta & 3,56 & 3,12 & $2,153^{*}$ \\
\hline opakowanie produktu & 3,13 & 2,86 & $-1,943^{*}$ \\
\hline promocja & 3,31 & 3,54 & $4,481^{* * * *}$ \\
\hline skład produktu & 3,57 & 3,04 & \\
\hline$t-$ statystyka $t ; p-$ poziom istotności; ${ }^{*} p \leq 0,05 ; * * p \leq 0,01 ; * * * p \leq 0,001$ & \\
\hline
\end{tabular}

Źródło: opracowanie własne.

Natomiast porównanie ważności czynników zakupu chemii gospodarczej i kosmetyków w grupie mężczyzn w Poznaniu w latach 2011-2013 pozwoliło na identyfikację siedmiu determinant, w zakresie których nastapiła zmiana znaczenia (tab. 6).

Analiza porównawcza zaprezentowanych w powyższych tabelach czynników (tab. 5 i tab. 6) pozwala na wyodrębnienie zbioru, w zakresie którego nastapiła zmiana znaczenia zarówno w przypadku kobiet, jak i mężczyzn. Są to: konsystencja produktu, łatwość użycia produktu, marka produktu i producent oraz skład produktu. W przypadku kobiet zmiana znaczenia czynników nastapiła w zakresie obsługi klienta, promocji, opakowania i kraju pochodzenia produktu, a mężczyzn - w zakresie skuteczności i szkodliwości tej kategorii produktów. 


\section{Tabela 6}

Porównanie znaczenia determinant zakupu chemii gospodarczej i kosmetyków w grupie mężczyzn w Poznaniu w latach 2011-2013

\begin{tabular}{|c|c|c|c|}
\hline Czynnik & 2011 & 2013 & $t / p$ \\
\hline konsystencja produktu & 3,20 & 2,91 & $2,152^{*}$ \\
\hline łatwość użycia produktu & 3,46 & 3,17 & $2,109 *$ \\
\hline marka produktu & 3,25 & 2,96 & $2,164^{*}$ \\
\hline producent & 3,19 & 2,79 & $2,821^{* *}$ \\
\hline skład produktu & 3,28 & 2,86 & $3,102^{* *}$ \\
\hline skuteczność produktu & 3,90 & 3,53 & $3,213^{* * *}$ \\
\hline szkodliwość produktu & 3,68 & 3,14 & $3,883^{* * *}$ \\
\hline
\end{tabular}

Źródło: opracowanie własne.

Kolejnym krokiem postępowania badawczego była identyfikacja statystycznie istotnych różnic $\mathrm{w}$ znaczeniu determinant zakupu chemii gospodarczej i kosmetyków w grupach kobiet (tab. 7) i mężczyzn (tab. 8) w Wielkopolsce w latach 2011-2013.

\section{Tabela 7}

Porównanie znaczenia determinant zakupu chemii gospodarczej i kosmetyków w grupie kobiet w Wielkopolsce (bez Poznania) w latach 2011-2013

\begin{tabular}{|c|c|c|c|}
\hline Czynnik & 2011 & 2013 & $t / p$ \\
\hline kraj pochodzenia produktu & 3,08 & 2,81 & $3,889 * * *$ \\
\hline marka produktu & 3,48 & 3,31 & $2,681^{* *}$ \\
\hline producent & 3,34 & 3,19 & $2,336^{*}$ \\
\hline miejsce zakupu produktu & 3,19 & 2,97 & $3,417^{* * *}$ \\
\hline nowość produktu & 2,91 & 2,73 & $2,598^{* *}$ \\
\hline opakowanie produktu & 3,25 & 3,07 & $2,996^{* *}$ \\
\hline skład produktu & 3,67 & 3,43 & $3,834^{* * *}$ \\
\hline szkodliwość produktu & 4,09 & 3,80 & $4,949 * * *$ \\
\hline wielkość opakowania & 3,70 & 3,45 & $4,317 * * *$ \\
\hline
\end{tabular}

Źródło: opracowanie własne. 


\section{Tabela 8}

Porównanie znaczenia determinant zakupu chemii gospodarczej i kosmetyków w grupie mężczyzn w Wielkopolsce (bez Poznania) w latach 2011-2013

\begin{tabular}{|c|c|c|c|}
\hline Czynnik & 2011 & 2013 & $t / p$ \\
\hline jakość produktu & 4,19 & 4,04 & $3,007 * *$ \\
\hline kraj pochodzenia produktu & 2,88 & 2,55 & $4,521^{* * *}$ \\
\hline łatwość użycia produktu & 3,56 & 3,42 & $2,263^{*}$ \\
\hline marka produktu & 3,37 & 3,12 & $3,533^{* * *}$ \\
\hline producent & 3,25 & 2,99 & $3,738 * * *$ \\
\hline miejsce zakupu produktu & 2,97 & 2,80 & $2,335^{*}$ \\
\hline nowość produktu & 2,81 & 2,59 & $3,206^{* * *}$ \\
\hline obsługa klienta & 3,54 & 3,38 & $2,414^{*}$ \\
\hline opakowanie produktu & 3,03 & 2,82 & $3,191^{* * *}$ \\
\hline skład produktu & 3,23 & 3,01 & $3,033^{* *}$ \\
\hline skuteczność produktu & 3,93 & 3,77 & $2,736^{* *}$ \\
\hline szkodliwość produktu & 3,75 & 3,43 & $4,767 * * *$ \\
\hline wielkość opakowania & 3,40 & 3,22 & $2,820 * *$ \\
\hline wydajność produktu & 3,91 & 3,75 & $2,769 * *$ \\
\hline zapach produktu & 3,85 & 3,72 & $2,068^{*}$ \\
\hline
\end{tabular}

Źródło: opracowanie własne.

Analiza uzyskanych wyników pozwoliła na wyróżnienie dziewięciu różnic w grupie kobiet oraz aż piętnastu różnic w grupie mężczyzn. Jeśli chodzi o determinanty, to zarówno w przypadku kobiet, jak i mężczyzn pokrywały się: marka produktu, kraj pochodzenia, producent, nowość produktu, opakowanie i skład produktu oraz wielkość opakowania. Niewatpliwie zaskoczenie stanowić może duża liczebność zbioru tych determinant wśród Wielkopolan, która odzwierciedla fakt zmniejszania się znaczenia branych pod uwagę czynników w procesie zakupowym tych dóbr.

\section{DETERMINANTY ZAKUPÓW ODZIEŻY I OBUWIA}

Trzeci zbiór determinant zakupu, który poddany został ocenie, obejmował czynniki zakupu odzieży i obuwia (34) w latach 2011-2013 (wykres 3). Odzież i obuwie należą do grupy towarów zaspokajających podstawowe potrzeby konsumenckie, ale poziom wydatków w gospodarstwie domowym na te dobra oraz częstotliwość dokonywania zakupów w porównaniu z wcześniej omawianymi są 
zdecydowanie niższe ${ }^{10}$. Ponadto w ich przypadku dostrzegalna jest sezonowość dokonywanych zakupów (szczególnie w okresie lato-zima) oraz to, że znaczna rolę w decyzjach zakupowych kobiet odgrywać może moda, dlatego w zbiorze 34 czynników można znaleźć takie, których wcześniej nie poddawano ocenie.

Wykres 3

Ważność determinant zakupu odzieży i obuwia w Poznaniu i w Wielkopolsce w latach 2011-2013

Czynnik ekologiczność produktu gwarancja produktu jakość produktu kolor produktu kraj pochodzenia produktu marka/ wizerunek producent materiał/ tkanina produktu moda/ trend możliwość zwrotu produktu efekt naśladownictwa obsługa klienta ochrona ciała opinia innych osób przynależność do subkultury pora roku poziom dochodu praktyczność/ użyteczność osobiste preferencje/ nawyki promocja przyzwyczajenie rozmiar/ dop. produktu sezonowość „specjalna okazja” sposób wykonania produktu unikalność produktu warunki płatności kompletowanie „odzieży” wygląd produktu wygoda użytkowania zakupoholizm zużycie starej odzieży
Poznań

2011

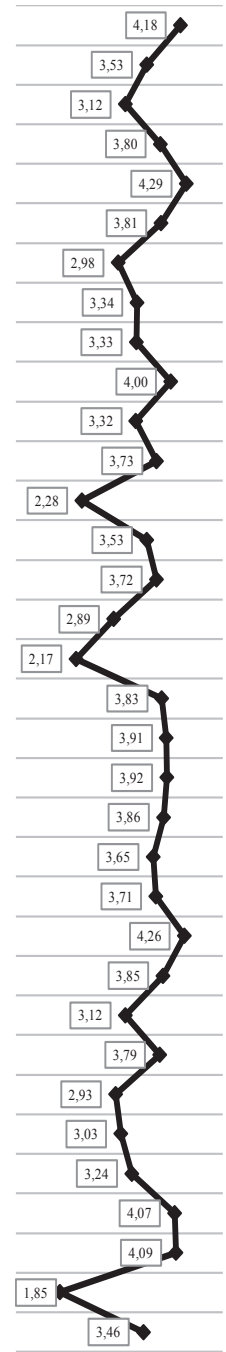

2013

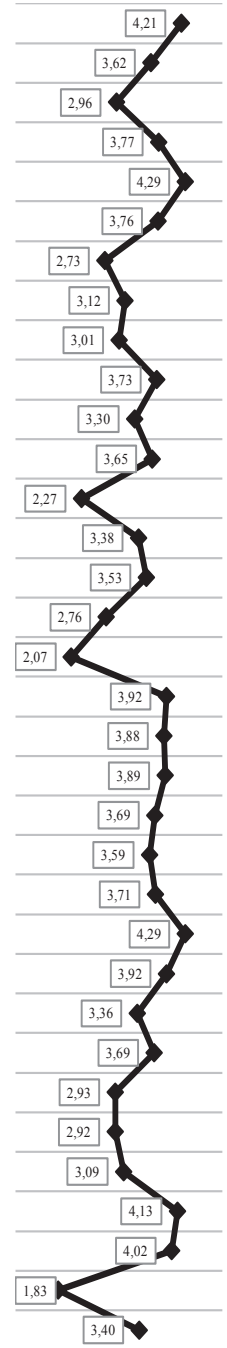

Wielkopolska (bez Poznania)

2011

2013

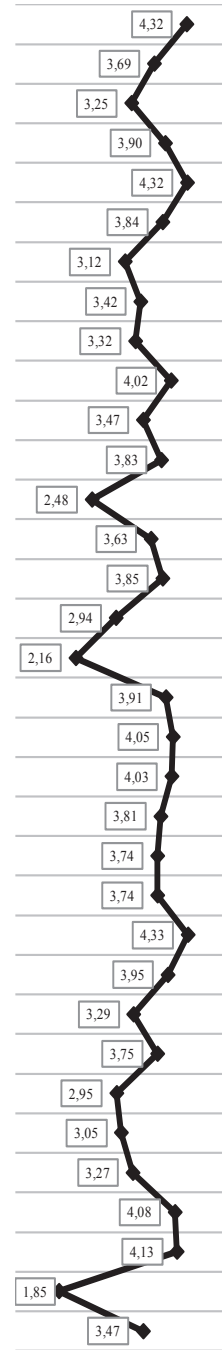

Źródło: opracowanie własne.

10 Zob. Sytuacja gospodarstw domowych w 2013 r. w świetle wyników badania budżetów gospodarstw domowych, GUS, Warszawa, 26.05.2014. 
Przeprowadzona analiza wyników w odniesieniu do wyróżnionych 34 determinant tej grupy towarów pozwoliła na wskazanie czynników najważniejszych, do których zaliczały się w 2013 r. przede wszystkim: cena $(\bar{x}=4,21$ - Poznań; $\bar{x}=4,37$ - Wielkopolska), jakość produktu ( $\bar{x}=4,29$ - Poznań; $\bar{x}=4,32-$ Wielkopolska), rozmiar/ dopasowanie produktu $(\bar{x}=4,29-$ Poznań; $\bar{x}=4,30-$ Wielkopolska), wygoda użytkowania $(\bar{x}=4,02-$ Poznań; $\bar{x}=4,07$ - Wielkopolska) oraz wygląd produktu $(\bar{x}=4,13$ - Poznań; $\bar{x}=3,96$ - Wielkopolska). W omówieniu determinant zakupów nie można pominąc tych, które znajdują się na drugim biegunie - czyli tych jednoznacznie wskazanych przez konsumentów jako mało istotne przy podejmowaniu decyzji o zakupie tej kategorii produktów. Zaliczyć do nich należy przede wszystkim: zakupoholizm ( $\bar{x}=1,83$ - Poznań; $\bar{x}=1,74-$ Wielkopolska), przynależność do subkultury $(\bar{x}=2,07$ - Poznań; $\bar{x}=2,02$ - Wielkopolska) oraz efekt naśladownictwa $(\bar{x}=2,27-$ Poznań; $\bar{x}=2,33-$ Wielkopolska).

Z kolei porównanie znaczenia determinant zakupowych odzieży i obuwia w latach 2011-2013 wskazuje na występowanie statystycznie istotnych różnic w zakresie jedenastu czynników w grupie kobiet (tab. 9) i w zakresie trzech czynników w grupie mężczyzn (tab. 10) spośród 34 uwzględnionych w przeprowadzonej analizie.

Znaczenie czynników, w zakresie których wskazano na statystycznie istotne różnice w grupach kobiet i mężczyzn w Poznaniu, było każdorazowo wyższe w 2011 r. Elementem wspólnym w tym zakresie okazała się zmiana znaczenia kraju pochodzenia produktu; w przypadku pozostałych czynników zakupu widoczne są wyraźne różnice w grupach kobiet i mężczyzn. Wśród mężczyzn zmiana znaczenia nastapiła w zakresie osobistych preferencji lub nawyków oraz promocji, a kobiet - zbiór obejmuje dodatkowych dziesięć czynników zakupowych (por. tab. 9).

\section{Tabela 9}

Porównanie znaczenia determinant zakupu odzieży i obuwia w grupie kobiet w Poznaniu w latach 2011-2013

\begin{tabular}{|l|c|c|c|}
\hline \multicolumn{1}{|c|}{ Czynnik } & $\mathbf{2 0 1 1}$ & $\mathbf{2 0 1 3}$ & $\boldsymbol{t} / \boldsymbol{p}$ \\
\hline ekologiczność produktu & 3,23 & 2,94 & $2,326^{*}$ \\
\hline kraj pochodzenia produktu & 3,08 & 2,81 & $2,078^{*}$ \\
\hline marka/ wizerunek & 3,37 & 3,03 & $2,595^{* *}$ \\
\hline producent & 3,38 & 2,85 & $3,877^{* * *}$ \\
\hline materiał/ tkanina produktu & 4,06 & 3,76 & $3,058^{* *}$ \\
\hline obsługa klienta & 3,59 & 3,35 & $2,182^{*}$ \\
\hline ochrona ciała & 3,72 & 3,49 & $2,011^{*}$ \\
\hline przynależność do subkultury & 2,19 & 1,90 & $2,066^{*}$ \\
\hline poziom dochodu & 4,01 & 3,76 & $2,313^{*}$ \\
\hline warunki płatności & 3,10 & 2,77 & $2,236^{*}$ \\
\hline kompletowanie „odzieży” & 3,36 & 3,12 & $1,964^{*}$ \\
\hline$t$ - statystyka $t ; p-$ poziom istotności; ${ }^{*} p \leq 0,05 ;{ }^{* *} p \leq 0,01 ; * * * p \leq 0,001$ & \\
\hline
\end{tabular}

Źródło: opracowanie własne. 


\section{Tabela 10}

Porównanie znaczenia determinant zakupu odzieży i obuwia w grupie mężczyzn w Poznaniu w latach 2011-2013

\begin{tabular}{|l|c|c|c|}
\hline \multicolumn{1}{|c|}{ Czynnik } & $\mathbf{2 0 1 1}$ & $\mathbf{2 0 1 3}$ & $\boldsymbol{t} / \boldsymbol{p}$ \\
\hline kraj pochodzenia produktu & 2,87 & 2,54 & $2,177^{*}$ \\
\hline osobiste preferencje/ nawyki & 3,81 & 3,56 & $2,252^{*}$ \\
\hline promocja & 3,61 & 3,38 & $2,021^{*}$ \\
\hline$t$ - statystyka $t ; p$ - poziom istotności; ${ }^{*} p \leq 0,05 ;{ }^{* *} p \leq 0,01 ;{ }^{* * *} p \leq 0,001$ \\
\hline
\end{tabular}

Źródło: opracowanie własne.

Z kolei porównanie znaczenia determinant zakupu odzieży i obuwia w Wielkopolsce w latach 2011-2013 pozwoliło na ustalenie czternastu statystycznie istotnych różnic w grupie kobiet (tab. 11) oraz osiemnastu w grupie mężczyzn (tab. 12).

\section{Tabela 11}

Porównanie znaczenia determinant zakupu odzieży i obuwia w grupie kobiet w Wielkopolsce (wyłączając Poznań) w latach 2011-2013

\begin{tabular}{|l|c|c|c|}
\hline \multicolumn{1}{|c|}{ Czynnik } & $\mathbf{2 0 1 1}$ & $\mathbf{2 0 1 3}$ & $\boldsymbol{t} / \boldsymbol{p}$ \\
\hline ekologiczność produktu & 3,33 & 3,03 & $4,779^{* * *}$ \\
\hline kraj pochodzenia produktu & 3,16 & 2,87 & $4,182^{* * *}$ \\
\hline marka/ wizerunek & 3,43 & 3,26 & $2,438^{*}$ \\
\hline producent & 3,28 & 3,14 & $1,964^{*}$ \\
\hline moda/ trend & 3,60 & 3,42 & $2,635^{* *}$ \\
\hline efekt naśladownictwa & 2,53 & 2,37 & $2,182^{*}$ \\
\hline przynależność do subkultury & 2,19 & 2,02 & $2,348^{*}$ \\
\hline pora roku & 3,95 & 3,78 & $2,977^{* *}$ \\
\hline sezonowość & 4,03 & 3,91 & $2,195^{*}$ \\
\hline unikalność produktu & 3,02 & 2,79 & $3,128^{* *}$ \\
\hline warunki płatności & 3,11 & 2,84 & $3,426^{* * *}$ \\
\hline kompletowanie „odzieży” & 3,44 & 3,22 & $3,342^{* * *}$ \\
\hline wygląd produktu & 4,18 & 4,07 & $2,310^{*}$ \\
\hline zużycie starej odzieży & 3,47 & 3,29 & $2,457^{*}$ \\
\hline$t$ - statystyka $t ; p-$ poziom istotności; ${ }^{*} p \leq 0,05 ; * * p \leq 0,01 ; * * * p \leq 0,001$ & \\
\hline
\end{tabular}

Źródło: opracowanie własne.

Zmiany znaczenia determinant zakupu odzieży i obuwia $\mathrm{w}$ przypadku mieszkańców Wielkopolski sa zdecydowanie częstsze niż mieszkańców stolicy województwa. To samo można powiedzieć o konsumentach mieszkających w Poznaniu - można tu wskazać zbiór czynników wspólnych oraz zbiór czyn- 
ników różnicujących badane osoby. Pierwszy z nich obejmuje ekologiczność produktu, kraj jego pochodzenia, markę/wizerunek, producenta, modę/trendy, porę roku, unikalność produktów, warunki płatności oraz posiadanie innych części garderoby danego producenta (kompletowanie garderoby). Pozostałe czynniki wyróżnione w tabelach (tab. 11 i tab. 12) różnicują konsumentów ze względu na płeć.

\section{Tabela 12}

Porównanie znaczenia determinant zakupu odzieży i obuwia w grupie mężczyzn w Wielkopolsce (bez Poznania) w latach 2011-2013

\begin{tabular}{|c|c|c|c|}
\hline Czynnik & 2011 & 2013 & $t / p$ \\
\hline dostępność produktu & 3,66 & 3,52 & $2,338^{*}$ \\
\hline ekologiczność produktu & 3,16 & 2,87 & $4,205^{* * *}$ \\
\hline kraj pochodzenia produktu & 3,06 & 2,70 & $4,981^{* * *}$ \\
\hline marka/ wizerunek & 3,41 & 3,22 & $2,588^{* *}$ \\
\hline producent & 3,36 & 3,12 & $3,225^{* * *}$ \\
\hline materiał/ tkanina produktu & 3,92 & 3,75 & $2,908^{* *}$ \\
\hline moda/ trend & 3,33 & 3,10 & $2,994^{* *}$ \\
\hline obsługa klienta & 3,56 & 3,44 & $1,929^{*}$ \\
\hline ochrona ciała & 3,83 & 3,59 & $4,154^{* * *}$ \\
\hline opinia innych osób & 2,89 & 2,74 & $2,093^{*}$ \\
\hline pora roku & 3,88 & 3,70 & $2,895^{* *}$ \\
\hline poziom dochodu & 4,01 & 3,84 & $3,066^{* *}$ \\
\hline przyzwyczajenie & 3,72 & 3,59 & $2,161^{*}$ \\
\hline unikalność produktu & 2,86 & 2,66 & $2,521^{*}$ \\
\hline warunki płatności & 2,99 & 2,79 & $2,547^{*}$ \\
\hline kompletowanie „odzieży” & 3,08 & 2,78 & $4,287 * * *$ \\
\hline wygląd produktu & 3,96 & 3,84 & $2,075^{*}$ \\
\hline zakupoholizm & 1,73 & 1,61 & $1,966^{*}$ \\
\hline \multicolumn{4}{|c|}{$t$ - statystyka $t ; p-$ poziom istotności; ${ }^{*} p \leq 0,05 ;{ }^{* *} p \leq 0,01 ;{ }^{* * *} p \leq 0,001$} \\
\hline
\end{tabular}

Źródło: opracowanie własne na podstawie przeprowadzonych badań empirycznych.

Dodatkowo należy zwrócić uwagę na zmiany w preferencjach zakupowych mężczyzn w zakresie zakupu odzieży lub obuwia, występujące ze względu na miejsce ich zamieszkania. W przypadku konsumentów z Poznania różnicowanie znaczenia determinant zakupu tej kategorii produktów w latach 2011-2013 występowało trzykrotnie, natomiast w Wielkopolsce - aż osiemnastokrotnie. 


\section{DETERMINANTY ZAKUPÓW DÓBR TRWAŁEGO UŻYTKU}

Ostatnią grupę towarów, której wyodrębniony zbiór determinant został poddany ocenie i analizie, stanowiły czynniki kształtujące zakupy dóbr trwałego użytku (wykres 4). W przypadku tej kategorii produktów, ze względu

\section{Wykres 4}

Ważność determinant zakupu dóbr trwałego użytku w Poznaniu i w Wielkopolsce w latach 2011-2013

Czynnik

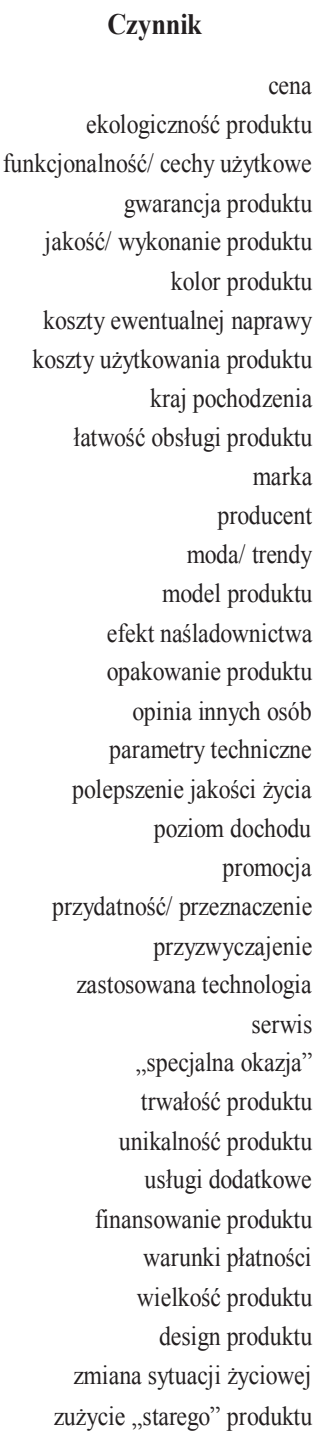

Poznań

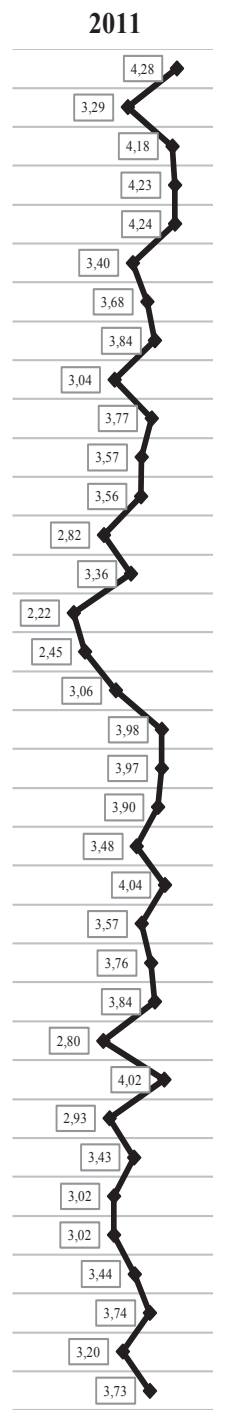

2013

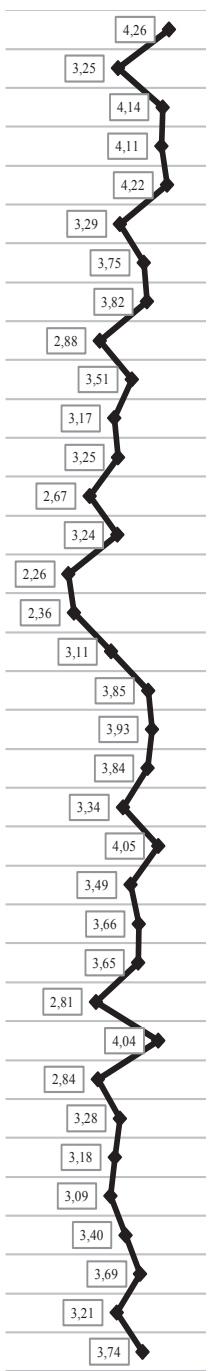

Wielkopolska (bez Poznania)

2011

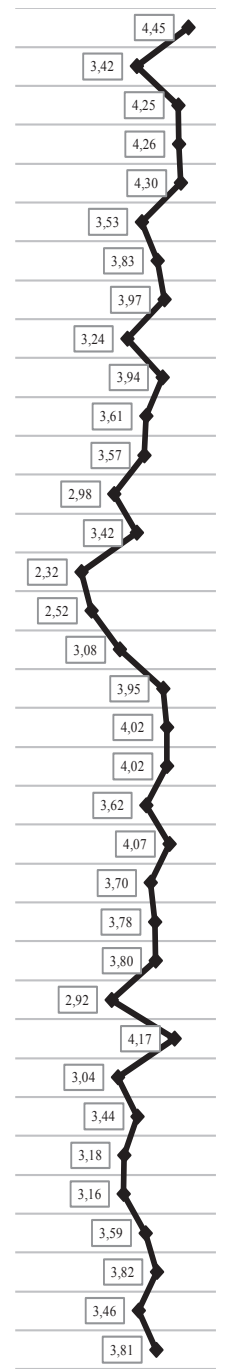

2013

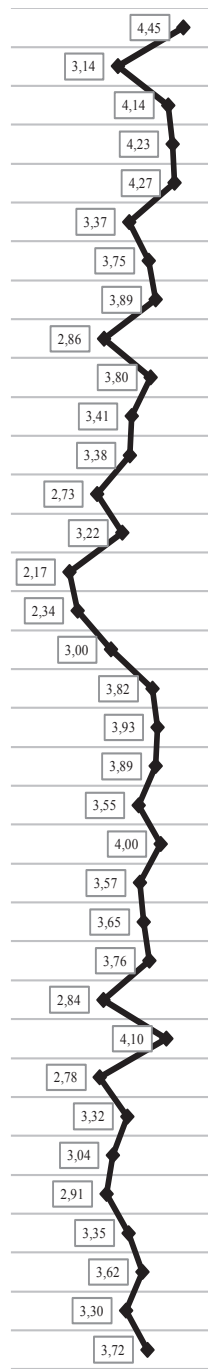

Źródło: opracowanie własne. 
na częstotliwość zakupu, specyfikę zaspokajanych potrzeb (znaczne uzależnienie od wielkości i rodzaju posiadanego mieszkania), ich znaczenia w budżecie gospodarstwa domowego oraz charakter decyzji zakupowej (liczba osób podejmujących decyzję) analizie merytorycznej poddano najliczniejszy zbiór zmiennych (35). Porównanie ważności determinant zakupu tej kategorii produktów przez mieszkańców Poznania oraz Wielkopolski zaprezentowano na wykresie 4. Wyniki przeprowadzonych badań empirycznych wskazuja jednoznacznie na grupę najważniejszych determinant zakupowych dóbr trwałego użytku, do których zaliczono: cenę $(\bar{x}=4,26$ - Poznań; $\bar{x}=4,45$ - Wielkopolska), cechy użytkowe produktu ( $\bar{x}=4,14$ - Poznań; $\bar{x}=4,14$ - Wielkopolska), jakość/ wykonanie produktu ( $\bar{x}=4,22$ - Poznań; $\bar{x}=4,27$ - Wielkopolska) oraz trwałość produktu ( $\bar{x}=4,04-$ Poznań; $\bar{x}=4,10-$ Wielkopolska $)$.

Podobnie jak w przypadku poprzednio omawianych grup towarów porównano znaczenie czynników zakupowych dóbr trwałego użytku w Poznaniu w latach 2011-2013. Uzyskane wyniki wskazują na większe znaczenie wyodrębnionych czynników w 2011 r. - zidentyfikowano dziewięć różnic w grupie kobiet (tab. 13) oraz trzy różnice w grupie mężczyzn (tab. 14).

Tabela 13

Porównanie znaczenia determinant zakupu dóbr trwałego użytku w grupie kobiet w Poznaniu w latach 2011-2013

\begin{tabular}{|c|c|c|c|}
\hline Czynnik & 2011 & 2013 & $t / p$ \\
\hline funkcjonalność/ cechy użytkowe & 4,25 & 4,07 & $1,965^{*}$ \\
\hline gwarancja produktu & 4,27 & 4,09 & $1,947^{*}$ \\
\hline kraj pochodzenia & 3,14 & 2,73 & $3,047^{* *}$ \\
\hline łatwość obsługi produktu & 3,80 & 3,49 & $2,630^{* *}$ \\
\hline marka & 3,50 & 2,95 & $4,392^{* * *}$ \\
\hline producent & 3,48 & 2,99 & $4,096^{* * *}$ \\
\hline serwis & 3,84 & 3,49 & $3,245^{* * *}$ \\
\hline unikalność produktu & 2,97 & 2,65 & $2,333^{*}$ \\
\hline usługi dodatkowe & 3,48 & 3,21 & $2,133^{*}$ \\
\hline
\end{tabular}

Źródło: opracowanie własne.

Wyniki testu $t$ w zakresie zmian znaczenia czynników zakupu dóbr trwałego użytku wskazuja, że ich rola ulega zmianom zdecydowanie rzadziej w przypadku mężczyzn (tab. 14). W tym przypadku zmalało znaczenie jedynie trzech czynników - łatwości obsługi, marki oraz promocji. W przypadku kobiet różnicowanie znaczenia determinant zakupu występuje również w zakresie innych elementów składajacych się na ofertę rynkową tej kategorii produktów - m.in. serwisu, gwarancji czy usług dodatkowych. 


\section{Tabela 14}

Porównanie znaczenia determinant zakupu dóbr trwałego użytku w grupie mężczyzn w Poznaniu w latach 2011-2013

\begin{tabular}{|l|c|c|c|}
\hline \multicolumn{1}{|c|}{ Czynnik } & $\mathbf{2 0 1 1}$ & $\mathbf{2 0 1 3}$ & $\boldsymbol{t} / \boldsymbol{p}$ \\
\hline latwość obsługi produktu & 3,73 & 3,43 & $2,298^{*}$ \\
\hline marka & 3,64 & 3,34 & $2,267^{*}$ \\
\hline promocja & 3,55 & 3,19 & $2,883^{*}$ \\
\hline \multicolumn{2}{|l|}{$t$ - statystyka $t ; p-$ poziom istotności; ${ }^{*} p \leq 0,05 ;{ }^{* *} p \leq 0,01 ;{ }^{* *} p \leq 0,001$} \\
\hline
\end{tabular}

Źródło: opracowanie własne.

Ostatnim obszarem postępowania badawczego w przypadku tej grupy dóbr było porównanie znaczenia czynników zakupu dóbr trwałego użytku w grupach osób mieszkających poza Poznaniem (tab. 15 i tab. 16). Wyniki testu $t$ wskazują na występowanie różnic w zakresie siedemnastu czynników w grupie kobiet (tab. 15) oraz w zakresie dwudziestu jeden czynników w grupie mężczyzn (tab. 16).

\section{Tabela 15}

Porównanie znaczenia determinant zakupu dóbr trwałego użytku w grupie kobiet w Wielkopolsce (wyłączając Poznań) w latach 2011-2013

\begin{tabular}{|c|c|c|c|}
\hline Czynnik & 2011 & 2013 & $t / p$ \\
\hline ekologiczność produktu & 3,51 & 3,29 & $3,299 * * *$ \\
\hline funkcjonalność/ cechy użytkowe & 4,32 & 4,19 & $3,120 * *$ \\
\hline kraj pochodzenia & 3,25 & 2,94 & $4,556^{* * *}$ \\
\hline marka & 3,57 & 3,44 & $2,045^{*}$ \\
\hline producent & 3,55 & 3,36 & $2,881^{* *}$ \\
\hline moda/ trendy & 2,99 & 2,80 & $2,666^{* *}$ \\
\hline model produktu & 3,40 & 3,24 & $2,338^{*}$ \\
\hline efekt naśladownictwa & 2,33 & 2,16 & $2,502 *$ \\
\hline opakowanie produktu & 2,57 & 2,43 & $2,002 *$ \\
\hline parametry techniczne & 3,86 & 3,75 & $1,966^{*}$ \\
\hline poziom dochodu & 4,08 & 3,92 & $2,900 * *$ \\
\hline unikalność produktu & 3,08 & 2,83 & $3,465 * * *$ \\
\hline usługi dodatkowe & 3,54 & 3,41 & $2,078 *$ \\
\hline warunki płatności & 3,24 & 2,90 & $4,615^{* * *}$ \\
\hline wielkość produktu & 3,67 & 3,48 & $3,253^{* * *}$ \\
\hline design produktu & 3,90 & 3,72 & $3,081^{* *}$ \\
\hline zmiana sytuacji życiowej & 3,52 & 3,36 & $2,381^{*}$ \\
\hline
\end{tabular}

Źródło: opracowanie własne. 
Uzyskane rezultaty analizy w przypadku tych dóbr wskazuja jednoznacznie, że znaczenie poszczególnych czynników w procesie zakupowym dóbr trwałego użytku ulega zmianom zdecydowanie częściej w porównaniu z pozostałymi kategoriami analizowanych produktów. Odzwierciedla to fakt występowania bardzo odmiennych sytuacji decyzyjnych (występowanie różnych czynników) w tym procesie, co nie powinno stanowić zaskoczenia. Ponieważ specyfika zaspokajanych potrzeb $\mathrm{w}$ gospodarstwie domowym $\mathrm{w}$ przypadku tej kategorii dóbr, ich rozwój technologiczny, poziom cen oraz konieczność posiadania odpowiedniego poziomu wiedzy do korzystania z nich (instrukcja użytkowania z reguły nie wystarczy) powodują sugerowaną wyżej

\section{Tabela 16}

Porównanie znaczenia determinant zakupu dóbr trwałego użytku w grupie mężczyzn w Wielkopolsce (bez Poznania) w latach 2011-2013

\begin{tabular}{|c|c|c|c|}
\hline Czynnik & 2011 & 2013 & $t / p$ \\
\hline ekologiczność produktu & 3,32 & 3,02 & $4,297^{* * * *}$ \\
\hline kolor produktu & 3,41 & 3,19 & $3,129 * *$ \\
\hline koszty użytkowania produktu & 3,95 & 3,79 & $2,797^{* *}$ \\
\hline kraj pochodzenia & 3,21 & 2,78 & $5,870 * * *$ \\
\hline łatwość obsługi produktu & 3,86 & 3,64 & $3,671^{* * *}$ \\
\hline marka & 3,63 & 3,40 & $3,541^{* * *}$ \\
\hline producent & 3,58 & 3,39 & $2,931^{* *}$ \\
\hline moda/ trendy & 2,95 & 2,64 & $4,211 * * *$ \\
\hline model produktu & 3,44 & 3,17 & $3,909 * * *$ \\
\hline opakowanie produktu & 2,46 & 2,26 & $2,857^{* * *}$ \\
\hline opinia innych osób & 3,11 & 2,95 & $2,094^{*}$ \\
\hline parametry techniczne & 4,06 & 3,88 & $3,114^{* *}$ \\
\hline polepszenie jakości życia & 3,99 & 3,88 & $2,220^{*}$ \\
\hline poziom dochodu & 3,97 & 3,84 & $2,263^{*}$ \\
\hline przyzwyczajenie & 3,69 & 3,53 & $2,635^{* *}$ \\
\hline zastosowana technologia & 3,84 & 3,65 & $3,327 * * *$ \\
\hline unikalność produktu & 2,99 & 2,74 & $3,301^{* * *}$ \\
\hline warunki płatności & 3,08 & 2,89 & $2,429^{*}$ \\
\hline wielkość produktu & 3,49 & 3,23 & $3,972^{* * *}$ \\
\hline design produktu & 3,74 & 3,53 & $3,490 * * *$ \\
\hline zmiana sytuacji życiowej & 3,40 & 3,25 & $2,163^{*}$ \\
\hline
\end{tabular}

Źródło: opracowanie własne. 
nieokreśloność decyzyjną (postrzegane ryzyko zakupu związane jest z potencjalnym wystapieniem dysonansu pozakupowego). Nie zależy również zapominać o tym, że bardzo widoczna zmiana znaczenia wyróżnionych determinant zakupu dóbr trwałego użytku, w porównaniu z pozostałymi kategoriami produktowymi, wynikać może $\mathrm{z}$ ich znaczenia $\mathrm{w}$ budżecie domowym konsumenta, co przekłada się na wnikliwą analizę i ocenę dokonywanych wyborów konsumenckich wraz konsekwencjami oraz poszukiwaniem innej alternatywy dla budżetu. W pośredni sposób potwierdza to również znaczenie czynnika związanego z koniecznością wymiany starego lub zużytego sprzętu, którego rola przewyższa znaczenie marki lub producenta dóbr trwałego użytku.

\section{ZAKOŃCZENIE}

Analiza wyznaczników (determinant, czynników) zakupu czterech kategorii produktów doprowadziła do określenia znaczenia wyróżnionych czynników oraz wskazania statystycznie istotnych różnic między grupami kobiet i mężczyzn mieszkających w Poznaniu i Wielkopolsce ze względu na średni poziom istotności tych czynników. Jak już wcześniej wspomniano, w zbiorze decydujących determinant zakupu, zarówno według ekspertów, jak i przedstawicieli przedsiębiorstw handlowych, najczęściej wskazywano cenę, jakość oraz markę. Zaprezentowane wyniki badań empirycznych częściowo potwierdzają te obserwacje i wyniki wcześniejszych badań, zwłaszcza w przypadku cen i jakości nabywanych produktów. Niemniej jednak pozostały układ (zbiór) wyznaczników w poszczególnych kategoriach produktów nie jest już tak jednoznaczny, a wręcz można mówić o zróżnicowaniu.

Dla grupy artykułów spożywczych bardzo ważnym dodatkowym czynnikiem jest termin ważności produktu (najważniejsza determinanta zakupu ważniejszy dla kobiet oraz konsumentów mieszkających poza Poznaniem) oraz smak produktu. W dalszej kolejności respondenci wskazali cenę (ważniejsza dla kobiet i osób spoza Poznania) oraz jakość produktu, na która szczególna uwagę zwracają konsumentki (nie występują z kolei różnice ze względu na miejsce zamieszkania nabywców). Rolę marki lub producenta produktu ocenić można co najwyżej jako średnią (rosnące znaczenie marek własnych). Co ciekawe, w tej kategorii produktów na drugim biegunie znalazła się nowość produktu, co potwierdza inne obserwacje wskazujące na wybór sprawdzonych produktów - jest to szczególnie widoczne w przypadku mieszkańców Poznania (w tej grupie konsumentów przyjmuje najniższe znaczenie).

Również dla chemii gospodarczej i kosmetyków w zbiorze trzech najważniejszych czynników nie można odnaleźć marki produktu lub producenta (ocenione jako średnio istotne). W tej kategorii produktów elementami zdecydowanie najważniejszymi są cena i jakość produktu. Największą uwagę do cen przywiąują konsumentki oraz osoby spoza Poznania, natomiast jakość jest szczególnie istotna w grupie kobiet (nie występują różnice w znaczeniu jakości ze względu na miejsce zamieszkania). Podobnie jak w przypadku 
artykułów spożywczych elementem ocenionym jako najmniej istotny okazała się nowość produktu - potwierdza to zarówno chęć zakupu produktów sprawdzonych (przy bardzo bogatej ofercie produktów), ale z drugiej strony wskazuje na problem komunikacji marketingowej w zakresie komercjalizacji nowych produktów (czynnik najmniej istotny w grupie mieszkańców Poznania).

Dla odzieży i obuwia do zbioru najważniejszych determinant zakupu zaliczyć należy, poza ceną i jakością produktu, elementy związane z komfortem użytkowania - rozmiar/dopasowanie produktu, wygląd oraz wygodę użytkowania. Rozmiar/dopasowanie produktu sa najważniejsze w grupie kobiet, na wygląd produktu zwracają szczególną uwagę konsumentki oraz mieszkańcy Poznania, natomiast wygoda użytkowania jest szczególnie ceniona przez Wielkopolan lub panie. Rola marki lub producenta jest średnia - zarówno wśród mieszkańców Poznania, jak i pozostałych konsumentów z Wielkopolski. Z kolei do elementów najmniej ważnych respondenci zaliczyli przynależność do subkultury oraz efekt naśladownictwa.

Rola producenta i marki rośnie w przypadku dóbr trwałego użytku zwłaszcza w grupie mężczyzn oraz mieszkańców spoza Poznania. Niemniej jednak porównanie ich roli do znaczenia ceny oraz jakości nabywanych produktów nie pozwala na zakwalifikowanie ich do zbioru najważniejszych - według badanych konsumentów elementami ważniejszymi są gwarancja produktu (porównywalne znaczenie w grupach kobiet i mężczyzn, wyższe w grupie konsumentów spoza Poznania), jego jakość i sposób wykonania (ważniejsze dla kobiet) oraz trwałość (najniższa istotność w grupie konsumentów z Poznania). Czynnikami najmniej ważnymi są natomiast efekt naśladownictwa, opakowanie produktu oraz moda lub trendy.

Wyniki przeprowadzonych badań empirycznych pozwoliły na potwierdzenie pierwszoplanowego znaczenia ceny oraz postrzeganej jakości nabywanych produktów. Eksponowana w wielu publikacjach znaczaca rola marki lub producenta nie jest już tak jednoznaczna w żadnej z badanych kategorii produktów.

Po zapoznaniu się z rezultatami badań może pojawić się pytanie o ich przydatność praktyczną w zarządzaniu miastem. Autorzy pragną wyjaśnić, że przedstawione wyniki są fragmentem wyników badań bardzo szerokiego obszaru zagadnień związanego z zachowaniami nabywczymi i konsumpcyjnymi Wielkopolan. Obejmują one również takie kwestie, jak: miejsca, częstotliwość i przesłanki zakupów w różnych typach sklepów, rodzaje i częstotliwość zakupów, w nowoczesnych kanałach sprzedaży czy konsumpcja w różnych typach placówek gastronomicznych. Przedstawiony wycinek badań, jak również całość wyników wzbogacają wiedzę o zachowaniach mieszkańców Poznania i województwa wielkopolskiego i jakości ich życia bardzo przydatną w:

- kształtowaniu ogólnych przesłanek w zakresie organizacji i planowania handlu na obszarze miasta oraz jego funkcjonowania;

- budowaniu relacji i związków wśród instytucji i podmiotów tworzących sieć handlowa;

- tworzeniu jednego z wymiarów koncepcji modelu zrównoważonego miasta; 
- realizacji przedsięwzięć marketingowych, takich jak kampanie społeczne dotyczace fair trade, czy przygotowaniu opracowań promocyjnych i analitycznych dla potencjalnych inwestorów ${ }^{11}$.

Nie można również zapomnieć o bardzo istotnym aspekcie, jaki przeprowadzone badania opisuja, a jest nim fragment mentalnego modelu zakupowego konsumenta w Poznaniu i Wielkopolsce. Przedstawione determinanty zakupów czterech grup towarów konsumpcyjnych stanowią jeden z istotnych elementów tego modelu, ukształtowane bowiem zostały na bazie własnych doświadczeń zebranych $\mathrm{w}$ trakcie zrealizowanych $\mathrm{w}$ przeszłości zakupów i doświadczeń (,,konsumpcyjnych”) z nabytymi towarami oraz ich własnej interpretacji. Tym samym rozpatrywane w szerszym kontekście, czyli z uwzględnieniem wymiarów demograficznych, psychograficznych i behawioralnych, mogą umożliwić wyjaśnienie celów i motywów zachowań nabywczych różnych segmentów mieszkańców Poznania i Wielkopolski.

dr Pawet Bartkowiak

Uniwersytet Ekonomiczny w Poznaniu

pawel.bartkowiak@ue.poznan.pl

prof. dr hab. Bogdan Sojkin

Uniwersytet Ekonomiczny w Poznaniu

bogdan.sojkin@ue.poznan.pl

\section{PURCHASE DETERMINANTS OF THE CONSUMPTION PRODUCTS \\ FOR INDIVIDUAL CONSUMERS \\ IN POZNAŃ AND THE WIELKOPOLSKA REGION}

Summary

The article offers an analysis of purchase determinants for individual consumers in Poznań and the Wielkopolska region (without Poznań) The analysis has been based on the outcomes of consumer research carried out in the years 2011 and 2013 at the Poznan University of Economics as well as on other research studies published in Polish sources. As a result, the study has specified and compared the basic groups of determinants shaping the purchase of foodstuffs and cosmetics, footwear, clothing, and consumer durables, as well as their variability in the years 2011 through 2013.

${ }_{11}$ Zob. http://www.spolecznosci.fairtrade.org.pl/reportaz-o-sprawiedliwym-handlu-w-poznaniu (dostęp: 15.06.2014). 